\title{
Pengaruh Model Penyimpanan Benih dan Jenis Pupuk Kandang Terhadap Pertumbuhan dan Hasil Jagung (Zea mays, L.)
}

\author{
Rudolf Evendi Wonkay ${ }^{b}$ dan Roberto I. C. O. Taolin ${ }^{\mathrm{b}}$ \\ ${ }^{a}$ Fakultas Pertanian, Universitas Timor, Kefamenanu, TTU - NTT, Indonesia. \\ ${ }^{b}$ Fakultas Pertanian, Universitas Timor, Kefamenanu, TTU - NTT, Indonesia.
}

\section{Article Info}

\section{Article history:}

Received 12 Januari 2016

Received in revised form 28 Mei 2016

Accepted 12 Agustus 2016

\section{Keywords:}

Model Penyimpanan Benih

Jenis Pupuk Kandang

Jagung

\section{Pendahuluan}

Jagung merupakan komoditas yang sangat penting selain padi terutama di negara-negera agraris seperti Indonesia. Jagung merupakan bahan pangan yang berperan dalam perekonomian, mudah diterima masyarakat, karena merupakan pangan tradisional. Jagung biasa dimanfaatkan sebagai bahan pangan, bahan baku industri dan pakan ternak. Jagung memiliki kandungan gizi seperti karbohidrat, protein dan lemak (Agustinus, 2008). Kandungan gizi jagung tidak kalah dengan beras atau terigu, bahkan jagung memiliki keunggulan karena merupakan pangan fungsional dengan kandungan serat pangan, unsur $\mathrm{Fe}$ dan beta-karoten (pro vitamin A) yang tinggi (Suarni, 2001).

Menurut data BPS NTT (2014), pada wilayah Kabupaten Timor Tengah Utara (TTU) luas panen jagung pada tahun 2014 adalah 25.114 ha dengan produktivitas $25,36 \mathrm{kw} / \mathrm{ha}$ dari produksi $63.677 \mathrm{ton}$, masih jauh lebih rendah dibanding produktivitas jagung di wilayah lain seperti Kabupaten Manggara Timur yang produktivitasnya mencapai $32,33 \mathrm{kw} / \mathrm{ha}$. Peningkatan produktivitas jagung dapat dilakukan dengan penerapan teknologi budidaya yang tepa misalnya penggunaan benih yang bermutu.

Benih jagung yang sesuai digunakan untuk penanaman yakni benih yang baik, bijinya mengkilat dan bebas hama dan penyakit karena benih memberikan andil yang besar untuk produktifitas. Pada waktu panen, petani biasanya memilih tongkol-tongkol terbaik dari tanaman terbaik untuk disimpan sebagai benih pada musim berikutnya (Subagio dan Aqil, 2013)

Berdasarkan hasil observasi, penyimpanan yang dilakukan masyaraka kabupaten TTU merupakan cara mengawetkan cadangan bahan makanan dar satu waktu kewaktu berikutnya dan untuk keperluan benih. Ada beberapa mode penyimpanan benih jagung masyarakat TTU, yaitu:

a. Penyimpanan di Dapur dengan Klobot (Pengasapan)

Model penyimpanan di dapur dengan klobot merupakan model penyimpanan yang sering digunakan masyarakat TTU pada umumnya. Pada kenyataan di masyarakat, benih yang memberikan hasil baik yakn penyimpanan dengan pengasapan di dapur. Penyimpan jagung model in dilakukan dengan cara jagung diikat enam puler yang disebut aisaf pada tempat gantung jagung atau disebut hau feo bahkan terkadang dalam bentuk beberapa kabutu (sepuluh aisaf yang diikat gabung lagi menjadi satu) yang disusun secara rapat. Jagung yang nanti digunakan untuk benih biasanya digantung jaraknya dekat api atau disebut tunaf. Tujuan dari mode penyimpanan agar jagung dapat bertahan lama dan terlindung dari hama bubuk. Lama penyimpanan ini biasanya mencapai 4-5 tahun.

b. Penyimpanan di Lopo atau Lumbung

Kebiasaan menyimpan jagung model seperti ini sudah menjadi tradisi bagi sebagian masyarakat TTU. Model penyimpanan ini, jagung dalam bentuk aisaf dan kabutu yang disimpan dalam lopo atau lumbung, jagung untuk benih disusun atau digantung pada sebuah kayu yang dipalang $\mathrm{d}$ antara kedua tiang nok atau fote dan khusus untuk konsumsi dan yang dijua disusun di sekeliling lumbung atau lopo. Hal ini dilakukan untuk mengawetkan jagung agar dapat bertahan lama dan melindungi jagung dari serangan hama bubuk. Model penyimpanan tersebut tidak dilakukan oleh seluruh masyarakat TTU hanya sebagian saja misalnya masyarakat di bagian Insana barat khususnya di Desa Tualele. Lama penyimpanan bisa mencapa satu tahun bahkan lebih.

\section{. Penyimpanan dalam Drum atau Jerigen}

Kebiasaan mayarakat TTU menyimpan benih dalam drum digunakan untuk menyimpan jagung lokal putih maupun kuning, jagung hibrida, jagung komposit. Di Kecamatan Bikomi Nilulat masyarakat menggunakan drum atau jerigen juga untuk meyimpan benih jagung atau penfini. Lama penyimpanannya 1-2 tahun. Banyak masyarakat yang beranggapan bahwa jagung yang disimpan di drum atau jerigen hanya untuk konsumsi, tetapi masyarakat di Kecamatan di bagian Insan barat khusunya di Desa Tualele menyimpan jagung di drum atau jerigen juga dijadikan sebagai benih atau pen fini.
Selain penggunaan benih bermutu, peningkatan hasil jagung dapat juga dilakukan dengan cara pemberian pupuk kandang. Menurut Khotimah (2010) penambahan pupuk organik merupakan suatu tindakan perbaikan lingkungan tumbuh tanaman yang antara lain dapat meningkatkan efisiensi pupuk. Hasil penelitian penggunaan pupuk organik, seperti kompos, pupuk kandang atau pupuk organik cair menunjukkan bahwa pupuk organik dapat meningkatkan produktivitas tanah dan efisiensi pemupukan serta mengurangi kebutuhan pupuk anorganik

Mega et al, (2008) menyatakan bahwa pupuk organik merupakan pupuk yang terbuat dari bahan-bahan organik yang didegradasikan secara organik. Sumber bahan baku organik ini dapat diperoleh dari bermacam-macam sumber seperti kotoran ternak, sampah rumah tangga non sintetis, limbah-limbah makanan atau minuman dan lain-lain. Biasanya untuk membuat pupuk organik ini, ditambahkan larutan mikroorganisme yang membantu mempercepat proses pendegradasian.

Pupuk organik dari kotoran ternak antara lain pupuk kandang sapi, pupuk kandang ayam dan pupuk kandang kambing. Permasalahanya adalah belum diketahui tentang pengaruh model penyimpanan benih yang biasa dilakukan masyarakat TTU dan jenis pupuk kandang terhadap pertumbuhan dan hasil jagung sehingga perlu dilakukan penelitian ini.

\section{Metode}

Penelitian telah dilaksanakan pada April sampai Agustus 2015 di kebun masyarakat, KM 5, Kelurahan Maubeli, Kecamatan Kota Kefamenanu, Kabupaten TTU. Penelitian mengunakan Rancangan Acak Kelompok (RAK) faktorial 3 x 3 yang diulang tiga kali. Faktor pertama adalah model penyimpanan benih $(\mathrm{P})$ yang terdiri dari tiga aras yaitu penyimpanan benih di dapur dengan klobot (pengasapan) $\left(\mathrm{p}_{1}\right)$, penyimpan di lopo atau lumbung $\left(\mathrm{p}_{2}\right)$ dan penyimpan dalam drum atau jerigen $\left(\mathrm{p}_{3}\right)$. Faktor kedua adalah jenis pupuk kandang $(\boldsymbol{J})$ yang terdiri dari tiga aras yaitu pupuk kandang sapi $\left(\mathrm{j}_{1}\right)$, pupuk kandang kambing $\left(\mathrm{j}_{2}\right)$ dan pupuk kandang ayam $\left(\mathrm{j}_{3}\right)$.

Data hasil pengamatan kemudian dianalisis dengan menggunakan sidik ragam (Anova) Rancangan Acak Kelompok (RAK). Rata-rata perlakuan selanjutnya diuji lanjut dengan menggunakan DMRT (Duncan multiple range test) dengan tingkat signifikasi 5\% sesuai petunjuk Gomez dan Gomez, (1995). Analisis data menggunakan program SAS 9.1.

\section{Hasil dan Pembahasan}

\subsection{Suhu Tanah}

Suhu tanah selama penelitian berfluktuasi dari pengamatan awal hingga pengamatan terakhir dengan kisaran suhu antara $27,3-35,5^{\circ} \mathrm{C}$. Hasil sidik ragam (Anova) menunjukkan tidak terjadi pengaruh interaksi antara model penyimpanan benih dan jenis pupuk kandang terhadap suhu tanah setiap waktu pengamatan.

Pengaruh utama baik perlakuan model penyimpanan benih dalam maupun jenis pupuk kandang juga tidak terjadi secara nyata terhadap suhu tanah setiap waktu pengamataan. Data Tabel 1. menunjukkan bahwa suhu tanah pada petak percobaan dengan perlakuan model penyimpanan benih dalam drum cenderung lebih tinggi saat pengamatan $25 \mathrm{HST}$, selanjutnya pada pengamatan $50 \mathrm{HST}$ dan 75 HST suhu tanah pada petak percobaan dengan perlakuan model penyimpanan benih dalam lumbung selalu cenderung lebih tinggi sedangkan suhu tanah pada petak percobaan dengan perlakuan model penyimpanan benih dalam drum selalu lebih rendah. Suhu tanah pada petak percobaan yang diberikan pupuk kandang ayam cenderung lebih tinggi saat pengamatan 25 HST, sedangkan pada pengamatan 50 HST suhu tanah pada petak percobaan yang diberikan pupuk kandang kambing cenderung lebih tinggi dan pada pengamatan 75 HST suhu tanah pada petak percobaan yang diberikan pupuk kandang sapi yang cenderung lebih tinggi. 
Tabel 1. Suhu Tanah $\left({ }^{\circ} \mathrm{C}\right)$

\begin{tabular}{|c|c|c|c|c|c|}
\hline \multirow{2}{*}{$\begin{array}{c}\text { Waktu } \\
\text { Pengamatan }\end{array}$} & \multirow{2}{*}{$\begin{array}{c}\text { Model } \\
\text { Penyimpanan } \\
\end{array}$} & \multicolumn{3}{|c|}{ Jenis Pupuk Kandang } & \multirow{2}{*}{ Rerata } \\
\hline & & Sapi & Kambing & Ayam & \\
\hline \multirow{4}{*}{$25 \mathrm{HST}$} & Klobot & $33,0 \mathrm{a}$ & $33,3 \mathrm{a}$ & $36,6 \mathrm{a}$ & $34,3 \mathrm{a}$ \\
\hline & Lumbung & $35,5 \mathrm{a}$ & 33,8 a & $34,8 \mathrm{a}$ & $34,7 \mathrm{a}$ \\
\hline & Drum & $35,1 \mathrm{a}$ & $35,0 \mathrm{a}$ & $36,6 \mathrm{a}$ & $35,5 \mathrm{a}$ \\
\hline & Rerata & $34,5 \mathrm{a}$ & $34,0 \mathrm{a}$ & $36,0 \mathrm{a}$ & $(-)$ \\
\hline \multirow{4}{*}{$50 \mathrm{HST}$} & Klobot & $30,3 \mathrm{a}$ & $30,0 \mathrm{a}$ & $30,5 \mathrm{a}$ & $30,3 \mathrm{a}$ \\
\hline & Lumbung & $31,0 \mathrm{a}$ & $31,2 \mathrm{a}$ & $30,0 \mathrm{a}$ & $30,8 \mathrm{a}$ \\
\hline & Drum & $27,3 \mathrm{a}$ & $30,2 \mathrm{a}$ & $30,6 \mathrm{a}$ & $29,4 \mathrm{a}$ \\
\hline & Rerata & $29,5 \mathrm{a}$ & $30,5 \mathrm{a}$ & $30,4 \mathrm{a}$ & $(-)$ \\
\hline \multirow{4}{*}{75 HST } & Klobot & $30,6 \mathrm{a}$ & $31,2 \mathrm{a}$ & $30,5 \mathrm{a}$ & $30,8 \mathrm{a}$ \\
\hline & Lumbung & $31,8 \mathrm{a}$ & $30,6 \mathrm{a}$ & $30,7 \mathrm{a}$ & $31,0 \mathrm{a}$ \\
\hline & Drum & $31,7 \mathrm{a}$ & $30,6 \mathrm{a}$ & $29,7 \mathrm{a}$ & $30,7 \mathrm{a}$ \\
\hline & Rerata & $31,4 \mathrm{a}$ & $30,8 \mathrm{a}$ & $30,3 \mathrm{a}$ & $(-)$ \\
\hline
\end{tabular}

\subsection{Kadar Lengas Tanah}

Kadar lengas tanah selama penelitian berfluktuasi dari pengamatan awal hingga pengamatan akhir. Kadar lengas tanah selama penelitian berkisar antara 10,7-37,4\%. Hasil sidik ragam (Anova) menunjukkan tidak terjadi pengaruh interaksi antara model penyimpanan benih dan jenis pupuk kandang terhadap kadar lengas tanah setiap waktu pengamatan.

Model penyimpanan benih tidak berpengaruh nyata terhadap kadar lengas tanah saat 25 HST tetapi data Tabel 2. menunjukkan bahwa kadar lengas tanah pada petak percobaan dengan perlakuan model penyimpanan benih menggunakan cara klobot cenderung lebih tinggi. Selanjutnya pada pengamatan 50 HST model penyimpanan benih berpengaruh nyata terhadap kadar lengas tanah dimana kadar lengas tanah pada petak percobaan dengan perlakuan penyimpanan benih dalam lumbung paling tinggi dan berbeda nyata dengan kadar lengas tanah pada petak percobaan dengan perlakuan penyimpanan benih dalam drum maupun dengan cara klobot. Pada pengamatan 75 HST model penyimpanan benih tidak berpengaruh nyata terhadap kadar lengas tanah tetapi kadar lengas tanah pada petak percobaan dengan perlakuan model penyimpanan benih menggunakan dalam drum cenderung lebih tinggi.

Jenis pupuk kandang tidak berpengaruh nyata terhadap kadar lengas setiap waktu pengamatan tetapi kadar lengas tanah pada petak percobaan yang diberikan pupuk kandang ayam cenderung lebih tinggi saat pengamatan 25 HST dan 50 HST, sedangkan pada pengamatan 75 HST kadar lengas tanah pada petak percobaan yang diberikan pupuk kandang kambing cenderung lebih tinggi.

Tabel 2. Kadar Lengas Tanah (\%)

\begin{tabular}{cccccc}
\hline \multirow{2}{*}{ Waktu } & Model & \multicolumn{3}{c}{ Jenis Pupuk Kandang } & \multirow{2}{*}{ Rerata } \\
\cline { 3 - 5 } Pengamatan & Penyimpanan & Sapi & Kambing & Ayam & \\
\hline \multirow{4}{*}{$25 \mathrm{HST}$} & Klobot & $10,7 \mathrm{a}$ & $12,3 \mathrm{a}$ & $25,4 \mathrm{a}$ & $16,1 \mathrm{a}$ \\
& Lumbung & $11,9 \mathrm{a}$ & $12,9 \mathrm{a}$ & $14,0 \mathrm{a}$ & $12,9 \mathrm{a}$ \\
& Drum & $12,4 \mathrm{a}$ & $18,6 \mathrm{a}$ & $14,3 \mathrm{a}$ & $15,1 \mathrm{a}$ \\
\cline { 2 - 5 } & Rerata & $11,7 \mathrm{a}$ & $14,6 \mathrm{a}$ & $17,9 \mathrm{a}$ & $(-)$ \\
\hline \multirow{4}{*}{$50 \mathrm{HST}$} & Klobot & $21,3 \mathrm{a}$ & $20,0 \mathrm{a}$ & $21,5 \mathrm{a}$ & $20,9 \mathrm{~b}$ \\
& Lumbung & $17,5 \mathrm{a}$ & $29,5 \mathrm{a}$ & $37,4 \mathrm{a}$ & $28,1 \mathrm{a}$ \\
& Drum & $20,3 \mathrm{a}$ & $17,2 \mathrm{a}$ & $20,7 \mathrm{a}$ & $19,4 \mathrm{~b}$ \\
\cline { 2 - 5 } & Rerata & $19,7 \mathrm{a}$ & $22,2 \mathrm{a}$ & $26,5 \mathrm{a}$ & $(-)$ \\
\hline \multirow{4}{*}{$75 \mathrm{HST}$} & Klobot & $12,2 \mathrm{a}$ & $19,4 \mathrm{a}$ & $20,2 \mathrm{a}$ & $17,3 \mathrm{a}$ \\
& Lumbung & $15,4 \mathrm{a}$ & $10,9 \mathrm{a}$ & $12,2 \mathrm{a}$ & $12,8 \mathrm{a}$ \\
& Drum & $21,0 \mathrm{a}$ & $22,1 \mathrm{a}$ & $11,6 \mathrm{a}$ & $18,2 \mathrm{a}$ \\
\cline { 2 - 5 } & Rerata & $16,2 \mathrm{a}$ & $17,4 \mathrm{a}$ & $14,7 \mathrm{a}$ & $(-)$ \\
\hline
\end{tabular}

Keterangan: Angka pada baris dan kolom yang diikuti dengan huruf yang sama tidak berbeda nyata menurut uji DMRT @ 5\%.(-) :Tidak Terjadi interaksi antar faktor

\subsection{Berat Volume Tanah}

Hasil sidik ragam (Anova) menunjukkan tidak terjadi interaksi antara model penyimpanan benih dan jenis pupuk terhadap berat volume tanah setiap waktu pengamatan.

Pengaruh utama baik perlakuan model penyimpanan benih dalam maupun jenis pupuk kandang juga tidak terjadi secara nyata terhadap berat volume tanah setiap waktu pengamataan. Data Tabel 3. menunjukkan bahwa berat volume tanah pada petak percobaan dengan perlakuan model penyimpanan benih dalam drum cenderung lebih tinggi saat pengamatan 25 HST, selanjutnya pada pengamatan 50 HST dan 75 HST berat volume tanah pada petak percobaan dengan perlakuan model penyimpanan benih menggunakan cara klobot selalu cenderung lebih tinggi sedangkan berat volume tanah pada petak percobaan dengan perlakuan model penyimpanan benih dalam lumbung selalu lebih rendah. Berat volume tanah pada petak percobaan yang diberikan pupuk kandang kambing cenderung lebih tinggi saat pengamatan 25 HST sedangkan pada pengamatan selanjutnya berat volume tanah pada petak percobaan yang diberikan pupuk kandang ayam selalu cenderung lebih tinggi.
Tabel 3. Berat Volume Tanah $\left(\mathrm{g} / \mathrm{cm}^{3}\right)$

\begin{tabular}{cccccc}
\hline Waktu & Model & \multicolumn{3}{c}{ Jenis Pupuk Kandang } & \multirow{2}{*}{ Rerata } \\
\cline { 3 - 5 } Pengamatan & Penyimpanan & Sapi & Kambing & Ayam & \\
\hline \multirow{3}{*}{$25 \mathrm{HST}$} & Klobot & $1,34 \mathrm{~b}$ & $1,46 \mathrm{a}$ & $1,23 \mathrm{~b}$ & $1,34 \mathrm{a}$ \\
& Lumbung & $1,26 \mathrm{~b}$ & $1,31 \mathrm{~b}$ & $1,43 \mathrm{~b}$ & $1,34 \mathrm{a}$ \\
& Drum & $1,30 \mathrm{~b}$ & $1,41 \mathrm{~b}$ & $1,42 \mathrm{~b}$ & $1,37 \mathrm{a}$ \\
\cline { 2 - 5 } & Rerata & $1,30 \mathrm{a}$ & $1,39 \mathrm{a}$ & $1,36 \mathrm{a}$ & $(-)$ \\
\hline \multirow{3}{*}{$50 \mathrm{HST}$} & Klobot & $1,56 \mathrm{~b}$ & $1,60 \mathrm{~b}$ & $1,58 \mathrm{~b}$ & $1,58 \mathrm{a}$ \\
& Lumbung & $1,53 \mathrm{~b}$ & $1,42 \mathrm{~b}$ & $1,61 \mathrm{~b}$ & $1,52 \mathrm{a}$ \\
& Drum & $1,62 \mathrm{a}$ & $1,54 \mathrm{~b}$ & $1,55 \mathrm{~b}$ & $1,57 \mathrm{a}$ \\
\cline { 2 - 5 } & Rerata & $1,57 \mathrm{a}$ & $1,52 \mathrm{a}$ & $1,58 \mathrm{a}$ & $(-)$ \\
\hline \multirow{3}{*}{$75 \mathrm{HST}$} & Klobot & $1,50 \mathrm{a}$ & $1,43 \mathrm{a}$ & $1,48 \mathrm{a}$ & $1,47 \mathrm{a}$ \\
& Lumbung & $1,39 \mathrm{a}$ & $1,27 \mathrm{a}$ & $1,57 \mathrm{a}$ & $1,41 \mathrm{a}$ \\
& Drum & $1,47 \mathrm{a}$ & $1,33 \mathrm{a}$ & $1,51 \mathrm{a}$ & $1,44 \mathrm{a}$ \\
\cline { 2 - 4 } Keterangan : & Angka pada baris dan kolom yang diikuti dengan huruf yang sama tidak \\
& Rerata & $1,45 \mathrm{a}$ & $1,35 \mathrm{a}$ & $1,52 \mathrm{a}$ & $(-)$ \\
& berbeda nyata menurut uji DMRT @ 5\%. (-) :Tidak Terjadi interaksi antar \\
& faktor & & & &
\end{tabular}

\subsection{Tinggi Tanaman}

Tanaman terus bertambah tinggi selama penelitian. Hasil analisis ragam (Anova) menunjukan tidak terjadi interaksi antara perlakuan model penyimpanan benih dan jenis pupuk kandang terhadap tinggi tanaman setiap waktu pengamatan.

Model penyimpanan benih berpengaruh nyata terhadap tinggi tanaman saat 14 HST dimana tanaman yang sebelum tanam benihnya disimpan dalam drum paling tinggi dan berbeda nyata dengan tinggi tanaman yang sebelum tanam benihnya disimpan dalam lumbung maupun dengan cara klobot. Pada pengamatan selanjutnya yakni 35 HST dan 56 HST model penyimpanan benih tidak berpengaruh nyata terhadap tinggi tanaman tetapi tanaman yang sebelum tanam benihnya disimpan dalam drum selalu cenderung lebih tinggi. Jenis pupuk kandang juga tidak berpengaruh nyata terhadap tinggi tanaman setiap waktu pengamatan tetapi tanaman yang diberikan pupuk kandang kambing selalu cenderung lebih tinggi.

\begin{tabular}{|c|c|c|c|c|c|}
\hline \multirow{2}{*}{$\begin{array}{c}\text { Waktu } \\
\text { Pengamatan }\end{array}$} & \multirow{2}{*}{$\begin{array}{c}\text { Model } \\
\text { Penyimpanan }\end{array}$} & \multicolumn{3}{|c|}{ Jenis Pupuk Kandang } & \multirow{2}{*}{ Rerata } \\
\hline & & Sapi & Kambing & Ayam & \\
\hline \multirow{4}{*}{14 HST } & Klobot & $35,1 \mathrm{~b}$ & $41,0 \mathrm{a}$ & $36,3 \mathrm{a}$ & $37,5 \mathrm{~b}$ \\
\hline & Lumbung & $37,0 \mathrm{a}$ & $37,4 \mathrm{a}$ & $34,2 \mathrm{c}$ & $36,2 \mathrm{~b}$ \\
\hline & Drum & $41,4 \mathrm{a}$ & $41,0 \mathrm{a}$ & $40,3 \mathrm{a}$ & $40,9 \mathrm{a}$ \\
\hline & Rerata & $37,8 \mathrm{a}$ & $39,8 \mathrm{a}$ & $37,0 \mathrm{a}$ & $(-)$ \\
\hline \multirow{4}{*}{$35 \mathrm{HST}$} & Klobot & $117,7 \mathrm{a}$ & $125,0 \mathrm{a}$ & $116,8 \mathrm{a}$ & $119,8 \mathrm{a}$ \\
\hline & Lumbung & $120,3 \mathrm{a}$ & $117,1 \mathrm{a}$ & $121,9 \mathrm{a}$ & $119,8 \mathrm{a}$ \\
\hline & Drum & $127,3 \mathrm{a}$ & $127,6 \mathrm{a}$ & $124,7 \mathrm{a}$ & $126,5 \mathrm{a}$ \\
\hline & Rerata & $121,8 \mathrm{a}$ & $123,2 \mathrm{a}$ & $121,1 \mathrm{a}$ & $(-)$ \\
\hline \multirow{4}{*}{$56 \mathrm{HST}$} & Klobot & $199,9 \mathrm{a}$ & $219,1 \mathrm{a}$ & $212,2 \mathrm{a}$ & $210,4 \mathrm{a}$ \\
\hline & Lumbung & $213,1 \mathrm{a}$ & $219,1 \mathrm{a}$ & $210,3 \mathrm{a}$ & $214,2 \mathrm{a}$ \\
\hline & Drum & $225,9 \mathrm{a}$ & $221,8 \mathrm{a}$ & $220,3 \mathrm{a}$ & $222,6 \mathrm{a}$ \\
\hline & Rerata & $213,0 \mathrm{a}$ & $220,0 \mathrm{a}$ & $214,2 \mathrm{a}$ & $(-)$ \\
\hline terangan & $\begin{array}{l}\text { Angka pada ba } \\
\text { berbeda nyata } \mathrm{m} \\
\text { faktor }\end{array}$ & an kolon & g diikuti d & $\begin{array}{l}\mathrm{n} \text { huruf } \\
\text { lak Terj }\end{array}$ & $\begin{array}{l}\text { sama tida } \\
\text { raksi ant }\end{array}$ \\
\hline
\end{tabular}

\subsection{Diameter Batang}

Batang tanaman terus bertambah besar selama penelitian. Hasil sidik ragam (Anova) menunjukkan bahwa tidak terjadi pengaruh interaksi antara model penyimpanan benih dan jenis pupuk kandang terhadap diameter batang setiap waktu pengamatan.

Tabel 5. Diameter Batang (cm)

\begin{tabular}{cccccc}
\hline Waktu & Model & \multicolumn{3}{c}{ Jenis Pupuk Kandang } & \multirow{2}{*}{ Rerata } \\
\cline { 3 - 5 } Pengamatan & Penyimpanan & Sapi & Kambing & Ayam & \\
\hline \multirow{3}{*}{$14 \mathrm{HST}$} & Klobot & $0,49 \mathrm{~b}$ & $0,59 \mathrm{~b}$ & $0,57 \mathrm{~b}$ & $0,55 \mathrm{a}$ \\
& Lumbung & $0,56 \mathrm{~b}$ & $0,57 \mathrm{~b}$ & $0,54 \mathrm{~b}$ & $0,56 \mathrm{a}$ \\
& Drum & $0,59 \mathrm{~b}$ & $0,57 \mathrm{~b}$ & $0,60 \mathrm{a}$ & $0,58 \mathrm{a}$ \\
\cline { 2 - 5 } & Rerata & $0,55 \mathrm{a}$ & $0,58 \mathrm{a}$ & $0,57 \mathrm{a}$ & $(-)$ \\
\hline \multirow{3}{*}{$35 \mathrm{HST}$} & Klobot & $1,30 \mathrm{~b}$ & $1,38 \mathrm{~b}$ & $1,29 \mathrm{~b}$ & $1,32 \mathrm{a}$ \\
& Lumbung & $1,27 \mathrm{~b}$ & $1,45 \mathrm{a}$ & $1,37 \mathrm{~b}$ & $1,36 \mathrm{a}$ \\
& Drum & $1,45 \mathrm{a}$ & $1,41 \mathrm{~b}$ & $1,37 \mathrm{~b}$ & $1,41 \mathrm{a}$ \\
\cline { 2 - 5 } & Rerata & $1,34 \mathrm{a}$ & $1,41 \mathrm{a}$ & $1,34 \mathrm{a}$ & $(-)$ \\
\hline \multirow{5}{*}{$56 \mathrm{HST}$} & Klobot & $2,28 \mathrm{~b}$ & $2,26 \mathrm{~b}$ & $2,14 \mathrm{~b}$ & $2,23 \mathrm{a}$ \\
& Lumbung & $2,29 \mathrm{~b}$ & $2,44 \mathrm{~b}$ & $2,29 \mathrm{~b}$ & $2,34 \mathrm{a}$ \\
& Drum & $2,28 \mathrm{~b}$ & $2,38 \mathrm{~b}$ & $2,50 \mathrm{a}$ & $2,39 \mathrm{a}$ \\
\cline { 2 - 5 } & Rerata & $2,28 \mathrm{a}$ & $2,36 \mathrm{a}$ & $2,31 \mathrm{a}$ & $(-)$ \\
\hline \multirow{2}{*}{ Kerannnn}
\end{tabular}

Keterangan: Angka pada baris dan kolom yang diikuti dengan huruf yang sama tidak berbeda nyata menurut uji DMRT @ 5\%.(-) :Tidak Terjadi interaksi antar faktor

Model penyimpanan benih tidak berpengaruh nyata terhadap diameter batang setiap waktu pengamatan tetapi data Tabel 5. menunjukkan bahwa batang tanaman yang sebelum tanam benihnya disimpan dalam drum selalu cenderung 
lebih besar sedangkan batang tanaman yang sebelum tanam benihnya disimpan dengan cara klobot selalu paling kecil. Jenis pupuk kandang juga tidak berpengaruh nyata terhadap diameter batang tetapi batang tanaman yang diberikan pupuk kandang kambing cenderung lebih besar setiap kali pengamatan sedangkan batang tanaman yang diberikan pupuk kandang sapi paling kecil.

\subsection{Luas Daun}

Hasil sidik ragam (Anova) menunjukkan tidak terjadi pengaruh interaksi antara model penyimpanan benih dan jenis pupuk terhadap luas daun.

Pengaruh utama baik model penyimpanan benih maupun jenis pupuk kandang tidak berpengaruh nyata terhadap luas daun tetapi data Tabel 6 . menunjukkan bahwa permukaan daun tanaman yang sebelum tanam benihnya disimpan dalam lumbung cenderung lebih luas sedangkan permukaan daun tanaman yang sebelum tanam benihnya disimpan dengan cara klobot paling sempit. Permukaan daun tanaman yang diberikan pupuk kandang kambing cenderung lebih luas sedangkan permukaan daun tanaman yang diberikan pupuk kandang sapi paling sempit.

Tabel 6. Luas Daun $\left(\mathrm{cm}^{2}\right)$

\begin{tabular}{ccccc}
\hline Model & \multicolumn{3}{c}{ Jenis Pupuk Kandang } & \multirow{2}{*}{ Rerata } \\
\cline { 2 - 4 } Penyimpanan & Sapi & Kambing & Ayam & \\
\hline Klobot & $232,4 \mathrm{a}$ & $311,1 \mathrm{a}$ & $296,0 \mathrm{a}$ & $279,8 \mathrm{a}$ \\
Lumbung & $306,3 \mathrm{a}$ & $413,9 \mathrm{a}$ & $319,4 \mathrm{a}$ & $346,5 \mathrm{a}$ \\
Drum & $291,7 \mathrm{a}$ & $327,8 \mathrm{a}$ & $355,6 \mathrm{a}$ & $325,0 \mathrm{a}$ \\
\hline Rerata & $276,8 \mathrm{a}$ & $350,9 \mathrm{a}$ & $323,7 \mathrm{a}$ & $(-)$ \\
\hline
\end{tabular}

Keterangan : Angka pada baris dan kolom yang diikuti dengan huruf yang sama tidak berbeda nyata menurut uji DMRT @ 5\%.(-):Tidak Terjadi interaksi antar faktor

\subsection{Jumlah Tongkol}

Setiap tanaman yang benihnya disimpan dengan cara klobot, dalam lumbung maupun dalam drum rata-rata memiliki dua tongkol pada setiap tanamannya sehingga jumlah tongkol yang dihasilkan seragam baik pada setiap tanaman maupun dalam setiap petaknya. Jumlah tongkol per tanaman seperti yang terlihat pada Tabel 7.

\section{Tabel 7. Jumlah Tongkol Per Tanaman}

\begin{tabular}{ccccc}
\hline \multirow{2}{*}{ Model Penyimpanan } & \multicolumn{3}{c}{ Jenis Pupuk Kandang } & \multirow{2}{*}{ Rerata } \\
\cline { 2 - 4 } & Sapi & Kambing & Ayam & \\
\hline Klobot & 2,0 & 2,0 & 2,0 & 2,0 \\
Lumbung & 2,0 & 2,0 & 2,0 & 2,0 \\
Drum & 2,0 & 2,0 & 2,0 & 2,0 \\
\hline Rerata & 2,0 & 2,0 & 2,0 & \\
\hline
\end{tabular}

\subsection{Panjang Tongkol}

Hasil sidik ragam (Anova) menunjukkan tidak terjadi pengaruh interaksi antara model penyimpanan benih dan jenis pupuk terhadap panjang tongkol.

Pengaruh utama baik model penyimpanan benih maupun jenis pupuk kandang tidak berpengaruh nyata terhadap panjang tongkol tetapi data Tabel 8 . menunjukkan bahwa tongkol tanaman yang sebelum tanam benihnya disimpan dalam lumbung dan dengan cara klobot cenderung lebih panjang sedangkan tongkol tanaman yang sebelum tanam benihnya disimpan dalam drum paling pendek. Tongkol tanaman yang diberikan pupuk kandang kambing cenderung lebih panjang sedangkan tongkol tanaman yang diberikan pupuk kandang sapi paling pendek.

$\underline{\text { Tabel 8. Panjang Tongkol }(\mathrm{cm})}$

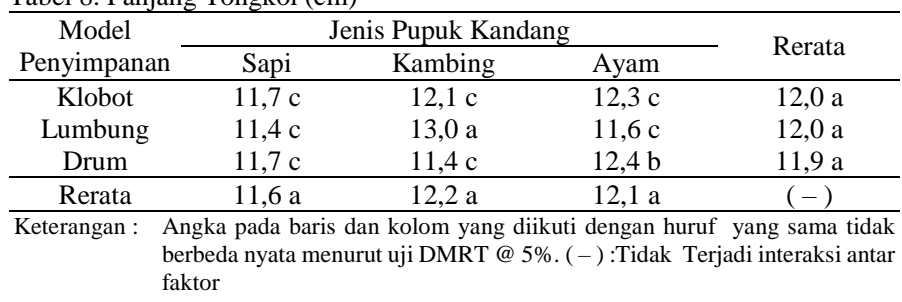

\subsection{Diameter Tongkol}

Hasil sidik ragam (Anova) menunjukkan tidak terjadi pengaruh interaksi antara model penyimpanan benih dan jenis pupuk kandang terhadap diameter tongkol.

Pengaruh utama baik model penyimpanan benih maupun jenis pupuk kandang tidak berpengaruh nyata terhadap diameter tongkol tetapi data Tabel 9. menunjukkan bahwa tongkol tanaman yang sebelum tanam benihnya disimpan dalam lumbung dan drum cenderung lebih besar sedangkan tongkol tanaman yang sebelum tanam benihnya disimpan dengan cara klobot paling kecil. Tongkol tanaman yang diberikan pupuk kandang ayam cenderung lebih besar sedangkan tongkol tanaman yang diberikan pupuk kandang sapi dan kambing lebih kecil.

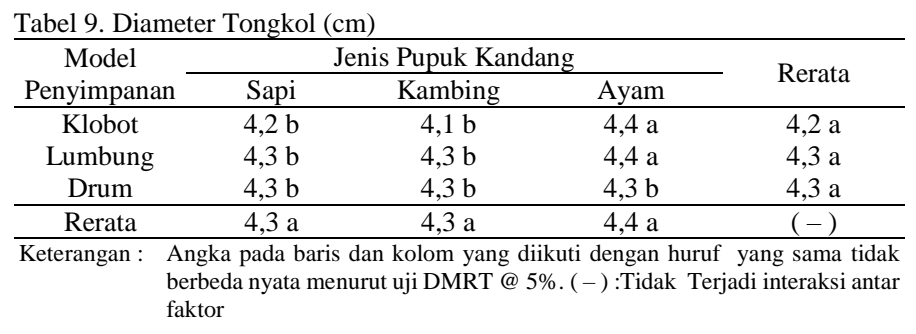

\subsection{Jumlah Baris Per Tongkol}

Hasil sidik ragam (Anova) menunjukkan tidak terjadi pengaruh interaksi antara model penyimpanan benih dan jenis pupuk kandang terhadap jumlah baris per tongkol.

Model penyimpanan benih tidak berpengaruh nyata terhadap jumlah baris per tongkol tetapi data Tabel 10. menunjukkan bahwa baris setiap tongkol tanaman yang sebelum tanam benihnya disimpan dalam drum cenderung lebih banyak sedangkan baris setiap tongkol tanaman yang sebelum tanam benihnya disimpan dengan cara klobot paling sedikit. Jenis pupuk kandang berpengaruh nyata terhadap jumlah baris per tongkol dimana baris setiap tongkol dari tanaman yang diberikan pupuk kandang ayam paling banyak dan berbeda nyata dengan jumlah baris per tongkol dari tanaman yang diberikan pupuk kandang kambing tetapi tidak berbeda nyata dengan jumlah baris per tongkol dari tanaman yang diberikan pupuk kandang sapi.

\section{Tabel 10. Jumlah Baris Per Tongkol}

\begin{tabular}{ccccc}
\hline Model & \multicolumn{3}{c}{ Jenis Pupuk Kandang } & \multirow{2}{*}{ Rerata } \\
\cline { 2 - 4 } Penyimpanan & Sapi & Kambing & Ayam & \\
\hline Klobot & $12,3 \mathrm{a}$ & $11,5 \mathrm{a}$ & $13,0 \mathrm{a}$ & $12,2 \mathrm{a}$ \\
Lumbung & $12,1 \mathrm{a}$ & $12,2 \mathrm{a}$ & $13,5 \mathrm{a}$ & $12,6 \mathrm{a}$ \\
Drum & $12,6 \mathrm{a}$ & $12,8 \mathrm{a}$ & $13,0 \mathrm{a}$ & $12,8 \mathrm{a}$ \\
\hline Rerata & $12,3 \mathrm{ab}$ & $12,2 \mathrm{~b}$ & $13,2 \mathrm{a}$ & $(-)$
\end{tabular}

Keterangan : Angka pada baris dan kolom yang diikuti dengan huruf yang sama tidak berbeda nyata menurut uji DMRT @ 5\%. (-) :Tidak Terjadi interaksi antar faktor

\subsection{Jumlah Biji Per Baris}

Hasil sidik ragam (Anova) menunjukkan tidak terjadi pengaruh interaksi antara model penyimpanan benih dan jenis pupuk kandang terhadap jumlah biji per baris.

Tabel 11. Jumlah Biji Per Baris

\begin{tabular}{ccccc}
\hline Model & \multicolumn{3}{c}{ Jenis Pupuk Kandang } & \multirow{2}{*}{ Rerata } \\
\cline { 2 - 4 } Penyimpanan & Sapi & Kambing & Ayam & \\
\hline Klobot & $20,2 \mathrm{a}$ & $20,6 \mathrm{a}$ & $21,8 \mathrm{a}$ & $20,9 \mathrm{a}$ \\
Lumbung & $19,5 \mathrm{a}$ & $20,6 \mathrm{a}$ & $20,0 \mathrm{a}$ & $20,1 \mathrm{a}$ \\
Drum & $18,1 \mathrm{a}$ & $19,1 \mathrm{a}$ & $21,4 \mathrm{a}$ & $19,5 \mathrm{a}$ \\
\hline Rerata & $19,3 \mathrm{a}$ & $20,1 \mathrm{a}$ & $21,1 \mathrm{a}$ & $(-)$
\end{tabular}

Keterangan : Angka pada baris dan kolom yang diikuti dengan huruf yang sama tidak berbeda nyata menurut uji DMRT @ 5\%. (-) :Tidak Terjadi interaksi antar faktor

Pengaruh utama baik model penyimpanan benih maupun jenis pupuk kandang tidak berpengaruh nyata terhadap jumlah biji per baris tetapi data Tabe 11. menunjukkan bahwa biji setiap baris tanaman yang sebelum tanam benihnya disimpan dengan cara klobot cenderung lebih banyak sedangkan biji setiap baris tanaman yang sebelum tanam benihnya disimpan dalam drum paling sedikit. Biji setiap baris dari tanaman yang diberikan pupuk kandang ayam cenderung lebih banyak sedangkan biji setiap baris tanaman yang diberikan pupuk kandang sapi paling sedikit.

\subsection{Berat Pipilan Kering Per Tanaman}

Hasil sidik ragam (Anova) menunjukkan tidak terjadi pengaruh interaksi antara model penyimpanan dan jenis pupuk kandang terhadap berat pipilan kering per tanaman.

Model penyimpanan benih juga tidak berpengaruh secara nyata terhadap berat pipilan kering per tanaman tetapi data Tabel 12. menunjukkan bahwa tanaman yang sebelum ditanam benihnya disimpan dengan cara lumbung menghasilkan pipilan kering setiap tanaman yang cenderung lebih berat dibanding tanaman yang sebelum ditanam benihnya disimpan dalam klobot maupun tanaman yang sebelum ditanam benihnya disimpan dalam drum yang menghasilkan pipilan kering setiap tanaman paling ringan. Sebaliknya jenis pupuk kandang berpengaruh nyata terhadap berat pipilan kering per tanaman dimana tanaman yang ditanam dengan jumlah pupuk kandang kambing menghasilkan pipilan kering per tanaman yang paling berat dan berbeda nyata dengan berat pipilan kering dari tanaman yang ditanam dengan pupuk kandang ayam maupun tanaman yang ditanam dengan pupuk kandang sapi yang menghasilkan pipilan kering per tanaman yang paling ringan. 
Tabel 12. Berat Pipilan Kering Per Tanaman (g)

\begin{tabular}{ccccc}
\hline Model & \multicolumn{3}{c}{ Jenis Pupuk Kandang } & \multirow{2}{*}{ Rerata } \\
\cline { 2 - 4 } Penyimpanan & Sapi & Kambing & Ayam & \\
\hline Klobot & $130,7 \mathrm{a}$ & $144,0 \mathrm{a}$ & $164,7 \mathrm{a}$ & $146,4 \mathrm{a}$ \\
Lumbung & $135,3 \mathrm{a}$ & $169,3 \mathrm{a}$ & $143,3 \mathrm{a}$ & $149,3 \mathrm{a}$ \\
Drum & $132,7 \mathrm{a}$ & $139,7 \mathrm{a}$ & $141,3 \mathrm{a}$ & $137,9 \mathrm{a}$ \\
\hline Rerata & $132,9 \mathrm{a}$ & $151,0 \mathrm{a}$ & $149,8 \mathrm{a}$ & $(-)$ \\
\hline
\end{tabular}

Keterangan: Angka pada baris dan kolom yang diikuti dengan huruf yang sama tidak berbeda nyata menurut uji DMRT @ 5\%. (-) :Tidak Terjadi interaksi antar faktor

\subsection{Berat 100 Biji}

Hasil sidik ragam (Anova) menunjukkan tidak terjadi pengaruh interaksi antara model penyimpanan benih dan jenis pupuk terhadap berat 100 biji.

Pengaruh utama baik model penyimpanan benih maupun jenis pupuk kandang tidak berpengaruh nyata terhadap berat 100 biji tetapi data Tabel 13 . menunjukkan bahwa setiap 100 biji dari tanaman yang sebelum tanam benihnya disimpan dengan cara klobot cenderung lebih berat sedangkan setiap 100 biji tanaman yang sebelum tanam benihnya disimpan dalam drum paling ringan. Berat 100 biji tanaman yang diberikan pupuk kandang ayam cenderung lebih berat sedangkan 100 biji tanaman yang diberikan pupuk kandang sapi paling ringan.

\section{Tabel 13. Berat 100 Biji (g)}

\begin{tabular}{ccccc}
\hline Model & \multicolumn{3}{c}{ Jenis Pupuk Kandang } & \multirow{2}{*}{ Rerata } \\
\cline { 2 - 4 } Penyimpanan & Sapi & Kambing & Ayam & \\
\hline Klobot & $33,1 \mathrm{a}$ & $30,8 \mathrm{a}$ & $33,4 \mathrm{a}$ & $32,4 \mathrm{a}$ \\
Lumbung & $28,5 \mathrm{a}$ & $34,2 \mathrm{a}$ & $34,0 \mathrm{a}$ & $32,2 \mathrm{a}$ \\
Drum & $29,8 \mathrm{a}$ & $29,2 \mathrm{a}$ & $28,7 \mathrm{a}$ & $29,2 \mathrm{a}$ \\
\hline Rerata & $30,5 \mathrm{a}$ & $31,4 \mathrm{a}$ & $32,0 \mathrm{a}$ & $(-)$
\end{tabular}

Keterangan : Angka pada baris dan kolom yang diikuti dengan huruf yang sama tidak berbeda nyata menurut uji DMRT @ 5\%. (-):Tidak Terjadi interaksi antar faktor

\subsection{Berat Pipilan Kering Per Petak}

Hasil sidik ragam (Anova) menunjukkan tidak terjadi pengaruh interaksi antara model penyimpanan benih dan jenis pupuk kandang terhadap berat pipilan kering per petak.

Tabel 14. Berat Pipilan Kering Per Petak (t/ha)

\begin{tabular}{ccccc}
\hline Model & \multicolumn{3}{c}{ Jenis Pupuk Kandang } & \multirow{2}{*}{ Rerata } \\
\cline { 2 - 4 } Penyimpanan & Sapi & Kambing & Ayam & \\
\hline Klobot & $0,867 \mathrm{~b}$ & $0,933 \mathrm{~b}$ & $1,000 \mathrm{a}$ & $0,933 \mathrm{a}$ \\
Lumbung & $0,911 \mathrm{~b}$ & $1,000 \mathrm{a}$ & $0,844 \mathrm{~b}$ & $0,919 \mathrm{a}$ \\
Drum & $0,889 \mathrm{~b}$ & $0,889 \mathrm{~b}$ & $0,956 \mathrm{~b}$ & $0,911 \mathrm{a}$ \\
\hline Rerata & $0,889 \mathrm{a}$ & $0,941 \mathrm{a}$ & $0,933 \mathrm{a}$ & $(-)$ \\
\hline
\end{tabular}

Keterangan : Angka pada baris dan kolom yang diikuti dengan huruf yang sama tidak berbeda nyata menurut uji DMRT @ 5\%. (-) :Tidak Terjadi interaksi antar faktor

Pengaruh utama baik model penyimpanan benih maupun jenis pupuk kandang tidak berpengaruh nyata terhadap berat pipilan kering per petak tetapi data Tabel 14. menunjukkan bahwa pipilan kering setiap petak dari tanaman yang sebelum tanam benihnya disimpan dengan cara klobot cenderung lebih berat sedangkan pipilan kering per petak dari tanaman yang sebelum tanam benihnya disimpan dalam drum paling ringan. Pipilan kering per petak dari tanaman yang diberikan pupuk kandang kambing cenderung lebih berat sedangkan pipilan kering per petak dari tanaman yang diberikan pupuk kandang sapi paling ringan.

\subsection{Berat Segar Berangkasan}

Hasil sidik ragam (Anova) menunjukkan tidak terjadi pengaruh interaksi antara model penyimpanan benih dan jenis pupuk kandang terhadap berat segar berangkasan.

Pengaruh utama baik model penyimpanan benih maupun jenis pupuk kandang tidak berpengaruh nyata terhadap berat segar berangkasan tetapi data Tabel 15. menunjukkan bahwa berangkasan segar tanaman yang sebelum tanam benihnya disimpan dalam drum cenderung lebih berat sedangkan berangkasan segar tanaman yang sebelum tanam benihnya disimpan dalam lumbung paling ringan. Berangkasan segar dari tanaman yang diberikan pupuk kandang ayam cenderung lebih berat sedangkan berangkasan segar dari tanaman yang diberikan pupuk kandang kambing paling ringan.

Tabel 15. Berat Segar Berangkasan (t/ha)

\begin{tabular}{ccccc}
\hline Model & \multicolumn{3}{c}{ Jenis Pupuk Kandang } & \multirow{2}{*}{ Rerata } \\
\cline { 2 - 4 } Penyimpanan & Sapi & Kambing & Ayam & \\
\hline Klobot & $4,867 \mathrm{~b}$ & $4,633 \mathrm{~b}$ & $4,933 \mathrm{~b}$ & $4,811 \mathrm{a}$ \\
Lumbung & $4,567 \mathrm{~b}$ & $4,767 \mathrm{~b}$ & $4,467 \mathrm{~b}$ & $4,600 \mathrm{a}$ \\
Drum & $5,000 \mathrm{~b}$ & $4,700 \mathrm{~b}$ & $5,333 \mathrm{a}$ & $5,011 \mathrm{a}$ \\
\hline Rerata & $4,811 \mathrm{a}$ & $4,700 \mathrm{a}$ & $4,911 \mathrm{a}$ & $(-)$ \\
\hline
\end{tabular}

Keterangan : Angka pada baris dan kolom yang diikuti dengan huruf yang sama tidak berbeda nyata menurut uji DMRT @ 5\%. (-) :Tidak Terjadi interaksi antar faktor

\subsection{Berat Kering Berangkasan}

Hasil sidik ragam (Anova) menunjukkan tidak terjadi pengaruh interaksi antara model penyimpanan benih dan jenis pupuk kandang terhadap berat kering berangkasan.

Tabel 16. Berat Kering Berangkasan (t/ha)

\begin{tabular}{|c|c|c|c|c|}
\hline \multirow{2}{*}{$\begin{array}{c}\text { Model } \\
\text { Penyimpanan }\end{array}$} & \multicolumn{3}{|c|}{ Jenis Pupuk Kandang } & \multirow{2}{*}{ Rerata } \\
\hline & Sapi & Kambing & Ayam & \\
\hline Klobot & $4,000 \mathrm{~b}$ & $3,200 \mathrm{c}$ & $3,933 \mathrm{~b}$ & $3,711 \mathrm{a}$ \\
\hline Lumbung & $3,600 \mathrm{~b}$ & $3,567 \mathrm{~b}$ & $3,467 \mathrm{~b}$ & $3,544 \mathrm{a}$ \\
\hline Drum & $3,767 \mathrm{~b}$ & $3,700 \mathrm{~b}$ & $4,267 \mathrm{a}$ & $3,911 \mathrm{a}$ \\
\hline Rerata & $3,789 \mathrm{a}$ & $3,489 \mathrm{a}$ & $3,889 \mathrm{a}$ & $(-)$ \\
\hline & 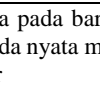 & olom yang & $\begin{array}{l}\text { dengan h } \\
- \text { ) :Tidak }\end{array}$ & \\
\hline
\end{tabular}

Pengaruh utama baik model penyimpanan benih maupun jenis pupuk kandang tidak berpengaruh nyata terhadap berat kering berangkasan tetapi data Tabel 16. menunjukkan bahwa berangkasan kering tanaman yang sebelum tanam benihnya disimpan dalam drum cenderung lebih berat sedangkan berangkasan kering tanaman yang sebelum tanam benihnya disimpan dalam lumbung paling ringan. Berangkasan kering dari tanaman yang diberikan pupuk kandang ayam cenderung lebih berat sedangkan berangkasan kering dari tanaman yang diberikan pupuk kandang kambing paling ringan.

\subsection{Indeks Panen}

Hasil sidik ragam (Anova) menunjukkan tidak terjadi pengaruh interaksi antara model penyimpanan benih dan jenis pupuk kandang terhadap indeks panen.

Pengaruh utama baik model penyimpanan benih maupun jenis pupuk kandang tidak berpengaruh nyata terhadap indeks panen tetapi data Tabel 17 menunjukkan bahwa indeks panen tanaman yang sebelum tanam benihnya disimpan dalam lumbung cenderung lebih tinggi sedangkan indeks panen tanaman yang sebelum tanam benihnya disimpan dalam drum paling rendah. Indeks panen tanaman yang diberikan pupuk kandang kambing cenderung lebih tinggi sedangkan indeks panen dari tanaman yang diberikan pupuk kandang sapi paling rendah.

\section{Tabel 17. Indeks Panen (\%)}

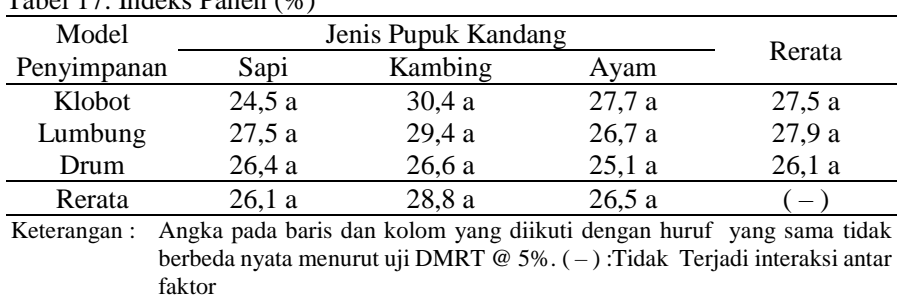

\subsection{Pembahasan}

Tanaman jagung yang sebelum ditanam benihnya disimpan dalam dapur dengan pengasapan (klobot) memiliki pertumbuhan vegetatif berupa tanaman yang tidak terlalu tinggi serta batang yang lebih kecil tetapi permukaan daunnya lebih luas. Tongkol yang dihasilkan lebih panjang tetapi berdiameter lebih kecil sehingga pada setiap tongkol memiliki baris yang lebih sedikit tetapi jumlah biji setiap barisnya lebih banyak, berat 100 biji juga lebih berat sehingga menghasilkan pipilan kering setiap petak yang paling berat, sedangkan berangkasan segar maupun kering tidak terlalu berat serta indeks panen tidak telalu tinggi.

Pemberian pupuk kandang kambing pada jagung menghasilkan pipilan kering per petak yang lebih berat walaupun berat 100 biji yang tidak terlalu berat, jumlah biji per baris yang tidak terlalu banyak, jumlah baris paling sedikit dengan tongkol yang panjang tetapi berdiameter kecil. Selain hasil berupa pipilan kering per petak, pemberian pupuk kandang kambing juga memberikan pertumbuhan vegetatif berupa tanaman yang lebih tinggi dengan batang yang lebih besar serta permukaan daun yang lebih luas.

\section{Simpulan}

Interaksi antara takaran arang sekam padi dan frekuensi penyemprotan terjadi pada kadar lengas 30 HST, tinggi tanaman 48 HST dan diameter batang 48 HST. Takaran Interaksi antara model penyimpanan benih dan jenis pupuk kandang tidak berpengaruh nyata terhadap semua parameter pertumbuhan dan hasil jagung. Model penyimpanan benih tidak berpengaruh nyata terhadap semua parameter pertumbuhan. jenis pupuk kandang tidak berpengaruh nyata terhadap semua parameter pertumbuhan. Penyimpanan benih dengan cara lumbung memberikan hasil jagung tertinggi. Pemberian pupuk kandang ayam memberikan hasil jagung tertinggi.

\section{Pustaka}

Agustinus. 2008. Kajian Vormulasi Isotermik Sorpsi Air Bubur Jagung Insan.

Sekolah Pascasarjana. Institut Pertanian Bogor.

BPS NTT. 2014.Nusa Tenggara Timur Dalam Angka. BPS NTT. Kupang. 
Gomez K A dan Gomez A A. 1995. Prosedur Statistik untuk Penelitian Pertanian. Edisi ke 2. Jakarta: UI Press.

Khotimah I K. 2010. Efisiensi Serapan dan Hasil Tanaman Padi (Oryza sativa L.) pada Berbagai Imbangan Pupuk Organik dan Pupuk Anorganik di Lahan Sawah Palur Sukoharjo. Fakultas Pertanian Universitas Sebelas Maret Surakarta.

Mega I M, Atmaja I W D, Widyarshana I D O, Adnyani I A S, Dibia I Ndan Darmawan D P. 2008. Pelatihan Pembuatan Pupuk Organik yang Berkualitas Dari Limbah Peternakan Sapi dan Babi di Desa Margadauhpuri, Kecamatan Marga, Kabupaten Tabanan.Fakultas Pertanian Universitas Udayana, Jl. PB. Sudirman Denpasar.

Suarni. 2001. Sosial Ekonomi Nasional (Susenas) Tahun 2008

Subagio H dan Aqil M. 2013. Pemetaan Pengembangan Varietas Unggul Jagung di Lahan Kering Iklim Kering. Balai Penelitian Tanaman Serealia. 